\title{
Institutions and rural economy in Rolpa district of Nepal
}

\section{Shiba Raj Pokhrel}

PhD Scholar, Central Department of Geography, Tribhuvan University, Kathmandu, Nepal

Email: pokhrelshiv@yahoo.com

\begin{abstract}
This paper aims to analyze a pertinent academic debate pragmatically whether institutions assist in promoting life standard and betterment of the common people or they act just as an instrument to perpetuate poverty and fulfill the interest of vested group. To accomplish this task, Marxist, Post-Marxist theories are taken into consideration in order to indicate how an institution or the process of institutionalization as such is debated and perceived in social science academia. Likewise, the research also uses the popular research methodology of pragmatism which focuses on data collection, analysis and field study. The research is conducted in Sunil Smirti Gaupalika (Rural Municipality) of Rolpa district and focuses on the role of institutions in order to transform particularly the economic life of the people. The research divides institutions into two parts. The first one includes the governmental local institution Gaupalika. The second part includes INGO/NGOs. This division enables to decipher and historicize what these government and non government institutions have done independently and collectively to uplift the life of target group. The research finds that INGO/NGOs and locals institution in the remote village like Sunil Smirti Gaupalika have played significant roles on uniting the economically poor and make individual and collective efforts to fight against poverty. They work to find out the poor and economically weak section of the society by setting target group, generating the awareness and providing conductive environment for putting collective effort in their fight against poverty to a certain extent. Therefore, these two types of institutions have been found tremendously supportive in uniting what Marx calls "have-nots" of Sunil Smirti Gaupalika. However, the research also finds that mostly Brahmin/Chhetri communities have been benefitted by these programs. In
\end{abstract}


comparison the ratio of economic growth between Brahmin-Chhetri community and Janjati community-Dalit community, the first one is found to be accelerating whereas the second one is slower and sluggish.

\section{DOI: http://dx.doi.org/10.3126/gjn.v12i1.23420}

Keywords: local institution, rural livelihood, enterprise development, social mobilization

\section{Introduction}

Agrawal and Perrin (2008) write that institutions are humanly created formal and informal mechanisms that shape social and individual expectations, interactions, and behavior. They further write different kinds of local institutions always exist within sociopolitical and ecological contexts. They claim research studies on the resources' use and distribution indicate that local resource users develop institutional arrangements to manage collectively and share the benefits received from resources such as forests, fisheries, grazing lands and water systems (Agrawal \& Perrin, 2008). Likewise, Ostrom (2005) agrees with them and concludes that local communities develop institutions to define their resource, user rights, resource allocation rules, monitoring mechanism, and conflict resolution arrangement to regulate and manage common pool resources.

Uphoff, Buck and Sjorslev (2006) classify such institutions into three broad categories: public (bureaucratic administrative units, and elected local governments), civic (membership and cooperative organizations), and private sectors (service and business organizations). According to Sick (2008), sociopolitical and ecological contexts influence their functioning and outcomes. Berkes (1989) opines that the institution's role in managing common resources has been a topic of research since the 1980s. Studies concluded that ineffective institutional arrangements can result in under or over exploitation of resources (Clark, 1973; Larson \& Bromley, 1990). As a local institution, the Non Government Organizations (NGOs) are playing a vital role for the economic development of the community. The main aim of the NGOs is promoting capacity building and self-reliance activities for sustainable development. Langran (2002), mentioned in his study that NGOs through capacity building help to sustain development. NGOs are often created in order to expand the capacities of people (Korten 1990). NGOs promote community self-reliance and empowerment through community-based organizations and participatory processes (Korten, 1990; Clark, 1999; Friedmann, 1992; Fowler, 1993; Edwards \& Hulme, 1994; Salamon, 1994). Hibbard \& Tang (2004) have pointed out the importance of NGOs' roles in developing community sustainably. 
Other forms of local institutions are community based organizations such as smallholder farmer groups (SFGs) which provide opportunities for people to participate at grassroots levels. Salami, Kamara \& Brixiova (2010) in their study pointed out community organization activities occur in farming systems with the household being important in planning, decision making and implementation of the projects. In this area, Magingxa \& Kamara (2003), Barham \& Chitemi (2008), World Bank (2006) and Anriquez \& Stamoulis (2007) added that expansion of smallholder farming through their organized groups stimulates faster rate of poverty reduction. In addition, smallholder farmer groups mediate intra-community conflicts, build infrastructure, attract other development actors (such as donors, NGOs) into the community and therefore, help many individuals to work more effectively and collectively (Resnick, 2004). Marx considered civil society as the sphere of market relations. To Marx, civil society was bourgeois and deserved to be abolished (Arato, 1990). At other times, the term also refers to the sum of all institutions between the family--the basic unit of social organization--and the state, including not only NGOs but also any other organizations such as political parties and armed groups (Foley \& Edwards, 1996). By some, the term is used even more broadly, encompassing not only the market and the public sphere, but also the family (Cohen \& Arato, 1992). In these contexts, this paper attempts to understand the role of institutions in enhancing rural economy in Rolpa district of Nepal.

\section{Materials and methods}

\section{Selection of the study area}

The research is based on the field study of Sunil Smriti Gaupalika of Rolpa district. The place has been selected as a research because it has heterogeneous geographical features with the elevation of 650 to 2350 meter. It consists of foot hills, tars, very steep and rugged mountainous terrain that covers the area of $156.55 \mathrm{sq} . \mathrm{km}$. and has a population of 28,213 (CBS, 2011). The most predominant caste and ethnic groups are: Chhetri (36\%), Magar (31\%), Dalit (17\%,), Brahmins (5\%) as well as Thakuri, Sanyasi and others (11\%) which collectively make this area a fertile and appropriate field for the study.

This study is based on mixed method approach and most of the scholars suggest that the philosophical orientation of mixed method research is pragmatism (Bryman, 2008; Greene, 2007; Johnson, Onwuegbuzie \& Turner, 2007). Pragmatism deals with the problems that exist with the specific situations in a reasonable and logical way instead of dealing with ideas and theories (Morgan, 2007). It claims that the choice of research philosophy is mostly determined by the research problem. 
This study design involves both quantitative and qualitative data collection techniques. In the qualitative approach four key concepts consists: flexibility, iteration, triangulation and creation of context (Gittleson, 1996). The primary data collection consists of both quantitative and qualitative data collection techniques. With regard to qualitative data collection, the observation method, key informant interview, unstructured interviews and focused group discussions were used. The household survey was made using household schedules to collect the quantitative data during the period of January to April, 2018. For the secondary data, the sources like Nepal Population Census Reports, Gaupalika profile, other available literatures, and archives were used.

The present research also takes theoretical interpretations and pragmatic aspect of NGOs in order to trace out and reduce their ambivalence in relation to their contribution on development. Considering these theorists, it can be predicted that NGOs serve more to the ruling handful class rather than the vast majority of people. The validity of the theorist will be critiqued and contested on the findings of the role NGOs have played in Sunil Smriti Gaupalika.

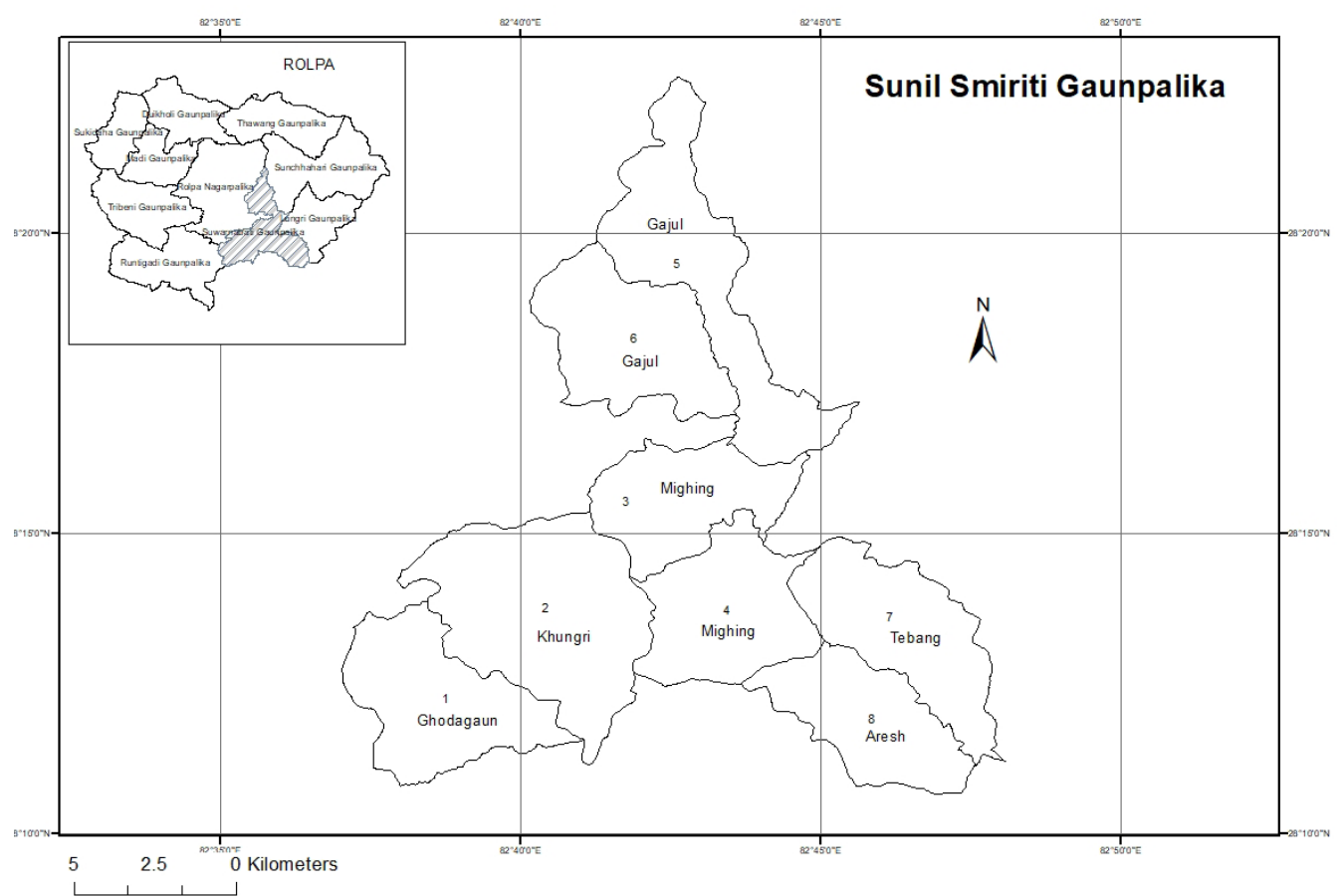

Figure 1: Location of Sunil Smriti Gaupalika 


\section{Selection of households for survey}

The present research executes stratified random sampling method to incorporate caste/ethnicity and altitudinal areas of the settlements. First based on the elevation, the whole Sunil Smriti Gaupalika is divided into two strata to make the study easy and comprehensive. In the first strata there are settlements having below 1200 meter including Khungri, Ghodagau and Mijhing and the settlement above 1200 consisting of Gajul, Aresh and Tewang. Secondly, the households have been divided into three strata: Brahmin/Chhetri, Janajati and Dalit. In each stratum, 30 households were sampled for the survey. The number of 30 sample size has been adopted on the basis of existing trends in doing researches on social sciences (Hesterberg, 1999; Efron \& Tibshirani, 1993; \& Davison \& Hinkley, 1997). So, a total of 180 households covering proportionally 30 in number for each three communities as per the elevation zones were surveyed.

\section{Analysis of the data}

Qualitative information gathered through different methods such as personal observations, focus group discussion, key informant interview and maintaining field diary by informal one-to-one conversations were used for contextual analysis. The data collected from the survey was edited, coded and entered in the computer. Then the data was checked for consistency and completeness. The Excel data sheet is used to analyze the data and for cross-tabulations. Data from primary and secondary sources were tabulated, analyzed and interpreted using descriptive statistical tools.

\section{Results and discussion}

In Sunil Smriti Gaupalika, local institutions, such as public institution, user groups, community based organizations (CBOs), and non-government organization have played a vital role on local economic development because they mobilize the local resources maintaining long-term base for productive activity. They have the peculiar capacity and specific knowledge to use the most efficient and sustainable way of local resources. Despite the fact, NGOs goal is to minimize the gap between the compatively poor and rich members within the target group. Some so-called upper class Brahmin and Chhetri have been more benefitted because of their previleges like having longer food sustainability, better education and better holding over the land. NGOs make it easy to institutionalize decision-making process and monitor it in the low cost. It is because they involve the local people. The decisions of user groups or local institutions are guided and based on community norms and consensus which minimizes significantly chances of conflict in the developing and implementing community level plans. In this process, NGOs play the role as a meditator. Such institutions facilitate to the local people 
for developing long-term vision by creating common goals and objectives. However, despite all these constructive efforts and contribution of INGOs/NGOs, the economic gap between the rich and poor members especially the so-called upper castes and Dalit communities prevails.

\section{Public institutions}

The public institutions refer to part of the government that deals with local service delivery to the people. The Constitution of Nepal, 2015 intends to transform the country from a centralized unitary state into a federal embraces the principles of republicanism, federalism, secularism, and inclusiveness in order to ensure economic equality, prosperity and social justice, by eliminating discrimination based on class, caste, region, language, religion and gender.

The constitution made a fundamental shift in the system, structure and functioning of governance in Nepal. Three levels of government are stipulated by the constitution. A new governance structures have been established at the provincial level and local level: 753 local level units (293 Nagarpalikas and 460 Gaunpalikas) in the 7 provinces have been established. The devolution of power is guaranteed by the constitution through exclusive and concurrent powers provided for in Schedules 5 to 9 of the constitution.

As mentioned in the schedule- 8 of the constitution of Nepal, some of the major tasks of these local government are: management of the local services, local level development plans and projects, basic and secondary education, basic health and sanitation, local roads, rural roads, agro-roads, irrigation, agriculture and animal husbandry, agroproducts management, animal health, cooperatives, water supply, small hydropower projects, alternative energy and disaster management.

According to the constitution, the three levels of government are based on principle of coordination, cooperation and are all-inclusive and comprehensive. Grants from the centre have been directly disbursed to the local level. Financial resources of education, health, agriculture, livestock, and infrastructures such as rural roads, irrigation, etc. have been provided to local governments. The service delivery staffs such as teachers, health workers, agriculture extension officers, etc. are directly reporting to the local government.

Following are the some of the major works performed by the Sunil Smiriti Gaupalika in enhancing of rural economy and creation of employment. 


\section{Social mobilization}

Social mobilization is defined as a process that engages and motivates wide range of citizen and allies to raise awareness and make them able to demand for a particular development objective through face-to-face dialogue. At the local level, rural municipality implements various social mobilization programs in order to strengthen decentralization and improve local governance. Such programs ensure effective, equal and inclusive delivery of basic services and empower all citizens primarily Disadvantaged Groups (DAGs). Citizen organization therefore is a common platform to interact and build community network.

Social mobilization is one of the key strategies executed to promote and strengthen community participation and critical engagement of citizens in local governance process in Sunil Smriti Gaupalika. For this, Citizen Awareness Centers (CACs) have been established in each wards inclusive to the poorest and Dalit community households. This program has covered more than fifty percent households in this area. It has motivated for the participation of citizens, especially the poor, women and socially and economically deprived communities in decision-making process and has increased the sense of accountability in them.

In addition to this, Sunil Smriti Gaupalika has also introduced livelihood improvement packages to support the members in initiating small income generation activities. These activities include goat raising, cattle farming, small-scale grocery shop, kitchen garden, and poultry farming. Around one hundred thousand was allocated in each Citizen Awareness Centers for this income generating purposes. Similarly, a budget of one hundred thousand rupees was provided to each CAC. The budget aims at fulfilling genuine and productive small infrastructure needs of the poor members of CACs and bringing constructive, tangible differences in their lives. As a result, 115 households from the poorest and Dalit communities benefited.

\section{Rural road}

The construction of rural roads started after 1995, with the program, "Built own village by ourselves". In the beginning, a budget of three hundred thousand rupees was provided to each Village Development Committee and now each Rural Municipalities have an annual grant of at least Rs 300 million from the central government for the infrastructure development. The major part of the central grant invested to construct rural roads (Table 1). 
Table 1: Characteristics of rural roads

\begin{tabular}{|c|c|c|c|}
\hline Elevation & Major settlement & Ward No. & $\begin{array}{l}\text { Total length of earthen } \\
\text { road net-work ( } \mathrm{Km} \text {.) }\end{array}$ \\
\hline \multirow{4}{*}{ Low elevation } & Ghodagau & 1 & 31 \\
\hline & Khungri & 2 & 29 \\
\hline & Mijhing & 3,4 & 25 \\
\hline & \multicolumn{2}{|r|}{ Sub Total } & 85 \\
\hline \multirow{4}{*}{ High elevation } & Gajul & 5,6 & 35 \\
\hline & Tebang & 7 & 32 \\
\hline & Aresh & 8 & 20 \\
\hline & \multicolumn{2}{|r|}{ Sub Total } & 87 \\
\hline \multicolumn{3}{|r|}{ Total } & 172 \\
\hline
\end{tabular}

Source: Field survey, 2018

Within the period between 1995 to 2018, $172 \mathrm{Km}$ earthen road was constructed in Sunil Smriti Gaupalika and which fostered the connectivity among the different communities of this area. It helped to connect the rural communities, provide market access to farms and farmland and create accessibility and social mobility for the villagers.

\section{Community forestry}

Community Forest User Groups are one of the well-established local institutions in this area. There are 59 CFUGs which manages 47.1 square kilometer of community forest.

Table 2: Community forest user groups

\begin{tabular}{|c|c|c|c|c|}
\hline Elevation & Settlement & Ward No. & Number & Area $(\mathrm{Sq} \mathrm{Km})$ \\
\hline \multirow{4}{*}{ Low elevation } & Ghodagau & 1 & 1 & 1.97 \\
\hline & Khungri & 2 & 10 & 13.39 \\
\hline & Mijhing & 3,4 & 19 & 12.21 \\
\hline & & Sub Total & 30 & 27.57 \\
\hline \multirow{4}{*}{ High elevation } & Gajul & 5,6 & 16 & 13.6 \\
\hline & Tebang & 7 & 2 & 0.74 \\
\hline & Aresh & 8 & 11 & 5.19 \\
\hline & & Sub Total & 29 & $\mathbf{1 9 . 5 3}$ \\
\hline \multicolumn{3}{|l|}{ Total } & 59 & 47.1 \\
\hline
\end{tabular}

Source: Field survey, 2018 
These CFGs mobilize the local community to manage the common pool resources with locally governed rules, norms and values. The major function of the CFUGs consists of employment and income generating activities: the members get benefitted from temporary jobs as forest guards and as workers to cut as well as collect the forest product time and again. They generate income by selling firewood, saplings, and other forest products. CFGs manage and protect the forest resources, products and contribute in rural livelihoods. They raise awareness on disaster risk reduction and emergency relief. They also work for capacity development of the members. In short, such community groups have helped "have-nots" to have a sense of ownership and accountability.

\section{Agriculture extension services}

As per the spirit of the Local Self Governance Act (LSGA), 1999 the devolution of agricultural extension services to the local elected bodies, the Ministry of Agricultural Development has formulated National Agricultural Extension Strategy (NAES). The objective of this strategy is to reform and reorient public sector agricultural extension service in order to strengthen decentralized agricultural extension services and ensure the access of the poor, deprived and socially excluded to the agricultural extension service. This is cost-effective and has need-based participatory delivery of agricultural services. It prioritizes and targets to the needs of different categories of farmers, particularly focused on small, poor and deprived. Under this program, there are different groups formed in Sunil Smirti Gaupalika.

\section{Farmers's group}

The supply of extension services have been maintained through the farmers's group. The objective is to place the farmers of the same interest together and carry out the collective efforts and activities. This has been very effective to bring the innovation to the groups and help to make each member equally responsible in activities and accessible to extension services focusing on economic growth to the poor. 
Shiba Raj Pokhrel / The Geographical Journal of Nepal Vol. 12: 135-152, 2019

Table 3: Farmer's groups

\begin{tabular}{|l|l|r|r|r|r|}
\hline \multirow{2}{*}{ Elevation } & \multirow{2}{*}{ Major settlement } & \multirow{2}{*}{ Number } & \multicolumn{3}{|c|}{ Total members } \\
\cline { 4 - 6 } & & & Female & Male & \multicolumn{1}{c|}{ Total } \\
\hline \multirow{4}{*}{$\begin{array}{l}\text { Low } \\
\text { elevation }\end{array}$} & Ghodagau & 2 & 31 & 0 & 31 \\
\cline { 4 - 7 } & Khungri & 6 & 83 & 38 & 121 \\
\cline { 4 - 7 } & Mijhing & 4 & 20 & 19 & 39 \\
\cline { 2 - 6 } & Sub Total & $\mathbf{1 2}$ & $\mathbf{1 3 4}$ & $\mathbf{5 7}$ & $\mathbf{1 9 1}$ \\
\hline \multirow{4}{*}{$\begin{array}{l}\text { High } \\
\text { elevation }\end{array}$} & Gajul & 8 & 24 & 70 & 94 \\
\cline { 2 - 6 } & Tebang & 2 & 4 & 12 & 16 \\
\cline { 2 - 6 } & Aresh & 1 & 2 & 27 & 29 \\
\cline { 2 - 6 } & Sub Total & $\mathbf{1 1}$ & $\mathbf{3 0}$ & $\mathbf{1 0 9}$ & $\mathbf{1 3 9}$ \\
\hline Total & & $\mathbf{1 6 4}$ & $\mathbf{1 6 6}$ & $\mathbf{3 3 0}$ \\
\hline
\end{tabular}

Source: Field survey, 2018

About 23 farmers group are functioning with 330 members. In the low topography about $70 \%$ are female while in high topography this figure is quite opposite, only $21 \%$ are female members.

Table 4: Goat rearing groups

\begin{tabular}{|c|c|c|c|c|c|}
\hline \multirow{2}{*}{ Elevation } & \multirow{2}{*}{ Major settlement } & \multirow{2}{*}{ Number } & \multicolumn{3}{|c|}{ Total members } \\
\hline & & & Female & Male & Total \\
\hline \multirow{4}{*}{ Low elevation } & Ghodagau & 1 & 8 & 18 & 26 \\
\hline & Khungri & 3 & 65 & 6 & 71 \\
\hline & Mijhing & 2 & 23 & 18 & 41 \\
\hline & Sub Total & 6 & 96 & 42 & 138 \\
\hline \multirow{4}{*}{ High elevation } & Gajul & 1 & 15 & 8 & 23 \\
\hline & Tebang & 1 & 10 & 13 & 23 \\
\hline & Aresh & 1 & 19 & 2 & 21 \\
\hline & Sub Total & 3 & 44 & 23 & 67 \\
\hline \multicolumn{2}{|l|}{ Total } & 9 & 140 & 65 & 205 \\
\hline
\end{tabular}

Source: Field survey, 2018

In total 205 members in the nine goats rearing groups are functioning. More than two third are female members. 


\section{Community based organizations (CBOs)}

Community-based organizations (CBOs) are local groups of people legitimized by customary or formal institutions acting in the community for the betterment of its members. These are the non-profit organizations which provide voluntary social services at local level. The CBOs play a significant role in improving the livelihood of their community members. The main objective of a $\mathrm{CBO}$ is to improve the social and economic well-being of every member. Membership is placed on equal level for all households in a community. Members of CBOs are mainly concerned on socioeconomic development of the community and these groups have developed linkages with governmental and non-governmental organizations. Besides this act, CBOs have also been immensely contributing to reduce social evils and bring social harmony. Additionally, these organizations mobilize members in declaring open defecation, increasing school enrollment, conducting immunization campaign, updating the list of senior citizens for distribution of social security among others. The members also engaged in addressing the social problems like witchery, untouchability, child marriage, violence against women and caste-based discrimination.

\section{Non-governmental organization (NGOs)}

Non-governmental organizations (NGOs) are important agents for the socio-economic development of the local community. Furthermore, NGOs are effective in mobilizing the poor and disadvantage communities, empower them to gain better livelihood and carry out projects at lower level with a pertinent question of equal benefit sharing and economic benefit sharing with in a target group. In this area, five major I/NGO are working with different programs. Among them, RUDAS Nepal and HUREC Nepal are working directly to enhance of rural economy in terms of increasing productivity and creation of employment.

Table 5: List of NGOs

\begin{tabular}{|c|l|l|}
\hline S.N. & \multicolumn{1}{|c|}{ Name of the I/NGOs } & \multicolumn{1}{c|}{ Major Activities } \\
\hline 1 & RUDAS Nepal & $\begin{array}{l}\text { Agriculture, Climate Change and } \\
\text { Governance }\end{array}$ \\
\hline 2 & HUREC Nepal & Micro-enterprise \\
\hline 3 & Nepal Red Cross Society & Water and Sanitation \\
\hline 4 & $\begin{array}{l}\text { Western Nepal Rural Drinking Water } \\
\text { and Sanitation }\end{array}$ & Water and Sanitation \\
\hline 5 & UNICEF & School Feeding \\
\hline
\end{tabular}

Source: Field survey, 2018 


\section{Agriculture development}

RUDAS Nepal, an NGO is providing training to enhance agriculture economy through community groups. As per the needs, this NGO also supports and provides essential inputs such as farming equipments, seeds and fertilizer for the vegetable and fruit farming. It mobilizes the resources to ensure the agriculture growth. As a result, there are more than 15 orange fruit farming in the high topography and around 20 vegetable farming in the low topography.

\section{Enterprise development}

HUREC Nepal, another significant NGO, helps the potential entrepreneurs on the areas of entrepreneurship training. It primarily works on small/micro scale income generating activities. This NGO also supports on linkage development with financial institutions and market network, provides new technology (knowledge or materials) to micro-entrepreneurs. As a result, among the survey households almost four percent households' main livelihood activities is enterprise development.

\section{Outreach of local institution to vulnerable communities}

The local institutions are mobilizing quite good number of household members and managing and mobilizing local resources as per the government norms. The study carried out an analysis whether local institution are reaching to the most vulnerable communities and sharing the benefits

Table 6: Membership of institutions

\begin{tabular}{|c|c|c|c|c|c|}
\hline \multirow[b]{2}{*}{ Elevation } & \multirow[b]{2}{*}{ Categories } & \multirow{2}{*}{$\begin{array}{c}\% \text { of } \\
\text { covered } \\
\text { households }\end{array}$} & \multirow{2}{*}{$\begin{array}{l}\% \text { of saving } \\
\text { households }\end{array}$} & \multicolumn{2}{|c|}{ Loan } \\
\hline & & & & $\begin{array}{l}\% \text { of } \mathrm{HHs} \\
\text { taking loan }\end{array}$ & $\begin{array}{c}\text { Loan } \\
\text { amount }\end{array}$ \\
\hline \multirow{4}{*}{$\begin{array}{l}\text { Low } \\
\text { elevation }\end{array}$} & Brahmin/Chhetri & 63.3 & 50.0 & 26.7 & 305,000 \\
\hline & Janajati & 53.3 & 40.0 & 50.0 & 357,000 \\
\hline & Dalit & 46.7 & 50.0 & 73.3 & 535,000 \\
\hline & Sub-total & 54.4 & 46.7 & 50.0 & $1,197,000$ \\
\hline \multirow{4}{*}{$\begin{array}{l}\text { High } \\
\text { elevation }\end{array}$} & Brahmin/Chhetri & 56.7 & 46.7 & 28.6 & 215,000 \\
\hline & Janajati & 50.0 & 50.0 & 80.0 & 855,000 \\
\hline & Dalit & 43.3 & 46.0 & 57.1 & 760,000 \\
\hline & Sub-total & 50.0 & 47.8 & 55.8 & $1,830,000$ \\
\hline & Total & 52.2 & 47.2 & 52.9 & $3,027,000$ \\
\hline
\end{tabular}

Source: Field survey, 2018 
Based on this finding, if we compare among the ethnicity, the Brahmin/Chhetri community have the highest coverage and the Dalit community has the lowest coverage in both geographical zones.

\section{Benefit sharing}

In order to obtain economic development, local institutions mobilize the local community for saving credit scheme. They support the communities to create jobs and promote income generation activities. In the area, around half of the CBOs have saving credit scheme by which half of its members benefited by the credit scheme, used mainly in the income generating activities.

Table 7: Households annual saving

\begin{tabular}{|l|l|r|r|r|r|r|r|}
\hline \multirow{4}{*}{$\begin{array}{c}\text { Elevation } \\
\text { Zone }\end{array}$} & \multicolumn{2}{|c|}{ Categories } & \multicolumn{6}{|c|}{ Percentage of HHs having annual saving (Rs.) } \\
\cline { 3 - 8 } & & $\begin{array}{c}\text { Zero } \\
\text { Saving }\end{array}$ & $\begin{array}{c}\text { Up to } \\
100,000\end{array}$ & $\begin{array}{c}100,001 \\
\text { to } \\
300,000\end{array}$ & $\begin{array}{c}300,001 \\
\text { to } \\
500,000\end{array}$ & $\begin{array}{c}\text { Above } \\
500,001\end{array}$ & Total \\
\hline \multirow{3}{*}{$\begin{array}{l}\text { Low } \\
\text { elevation }\end{array}$} & Brahmin/Chhetri & 13.3 & 30.0 & 30.0 & 13.3 & 13.3 & 100.0 \\
\cline { 2 - 8 } & Janajati & 26.7 & 50.0 & 20.0 & 3.3 & - & 100.0 \\
\cline { 2 - 8 } & Dalit & 40.0 & 43.3 & 16.7 & - & - & 100.0 \\
\cline { 2 - 8 } & Average & $\mathbf{2 6 . 7}$ & $\mathbf{4 1 . 1}$ & $\mathbf{2 2 . 2}$ & $\mathbf{5 . 6}$ & $\mathbf{4 . 4}$ & $\mathbf{1 0 0 . 0}$ \\
\hline \multirow{3}{*}{$\begin{array}{l}\text { High } \\
\text { elevation }\end{array}$} & Brahmin/Chhetri & 20.0 & 43.3 & 30.0 & 6.7 & - & 100.0 \\
\cline { 2 - 8 } & Janajati & 33.3 & 36.7 & 26.7 & 3.3 & - & 100.0 \\
\cline { 2 - 8 } & Dalit & 50.0 & 33.3 & 16.7 & - & - & 100.0 \\
\cline { 2 - 8 } & Average & $\mathbf{3 4 . 4}$ & $\mathbf{3 7 . 8}$ & $\mathbf{2 4 . 4}$ & $\mathbf{3 . 3}$ & - & $\mathbf{1 0 0 . 0}$ \\
\hline Total & & $\mathbf{3 0 . 6}$ & $\mathbf{3 9 . 4}$ & $\mathbf{2 3 . 3}$ & $\mathbf{4 . 4}$ & $\mathbf{2 . 2}$ & $\mathbf{1 0 0 . 0}$ \\
\hline
\end{tabular}

Source: Field survey, 2018

Despite the fact that local institutions either governmental or non-governmental have played enormous role to uplift the economic life of all the members, however, only the Brahmins and Chhetri communities have been benefitted mostly. The finding shows that there is zero percentage of Dalit and Janjati households which can save above more than five hundred thousand one. This happens mainly because most of the loans which Dalit and Janajati community take use to sustain their livelihood whereas Brahmins use the more amount of loan in income generating activities. It is because Brahmins community are less victim of food deficiency. The data clearly depicts that the local institutions 
have failed to reach and genuinely address the problems of the most vulnerable sections of the communities in Sunil Smirti Gaupalika.

\section{Conclusion}

The growth of rural economy of Sunil Smriti Gaupalika which results through increasing production and employment creation, is in fact found to be a combined efforts of various local institutions. First, these institutions have motivated the poor people to be united and make collective effort in their struggle against poverty as seen in different groups of this Gaupalika like farmers' group growing vegetables and fruits and goat rearing. Through the construction of local community like community forest users' group, these institutions have not only created income generating opportunity for the poor people but also have motivated to take ownership and accountability. This has also ensured the proper utilization of local resources to reduce the poverty. However, the result shows that they have not succeeded to bring equal economic growth of all members because they have neglected the historiocal background of their members from diverse backgrounds with in a target group. Consequently, NGOs/INGOs and other local institutions have still been perceived as agenst of capitalism and mere apparatus to carry on the stereotypes. They have been criticized for serving the dominant class in a society. As found in Sunil Smirti Gaupalika, the Brahmin-Chhetri community, the dominant class is more benefitted by the programs of such institutions. This unequal distribution of benefit takes place mainly because of the problem in the perspective of these institutions. These institutions look all the members of the group either BrahminChhetri community or Dalit-Janajati community with the monolithic principle. They have the same program with the same sort of assistances geared with the same rules and regulations to treat the poorest of poor and the dominant class. As a result, they fail to see the different social, economic, political and educational backgrounds of the people within the same group. In the present case, these institutions have failed to see the different levels of "have-nots". Dalit and Janjati can sustain their livelihood just for three months from agricultural produces, so they cannot be equally benefitted as of Brahmins who have more than ten months livelihood sustainability. Therefore, such institutions need to bring heterogeneity in their programs. Dalit and Janajati communities need programs and trainings which would make them more educated and more skillful. They also require distinct economic assistances that would help them to cope with sustaining their livelihood and increase the saving percentage as the dominant class.

Likewise, the research found almost all the institutions have focused their programs basically on agriculture and farming. But there are many places on non-farming sectors where institutions can work to generate the income. Janjati and Dalit communities would 
be more benefitted from such programs because they lack the sufficient land where they can cultivate food, rare animals as a profession. Instead, they take manual work as the source of income for their livelihood. During the research, it is also found that some of the Dalits do not even have the idea about the passport and process of obtaining it. These are some of the places where institutions can work by providing them economic support, education, training to enhance their skill so that they would be able either to invest in the local level or sell their skill in higher wages at the local, national and international level. Certainly, it requires NGOs/INGOs to break the boundary of their stereotypical working framework like farming and agriculture and find new avenues in non-farming sectors as well that will help to reduce the gap between poor and rich and uplift the economic status of haves-not genuinely.

\section{Reference}

Agrawal, A., Brown, D. G., Rao, G., Riolo R., Robinson, D. T. and Bommarito, M. (2013). Interactions between organizations and networks in common pool resource governance. Environmental Science \& Policy. 25: 138-146.

Agrawal, A., and Perrin, N. (2008). Climate adaptation, local institutions and rural livelihoods. Michigan: International Forestry Resources and Institutions Program, University of Michigan. In IFRI Working Paper \# W081-6.

Agrawal, A., Chhatre, A. (2006). Explaining success on the commons: Community forest governance in the Indian Himalaya. World Development 34 (1): 149-66.

Agrawal, A. (2001). Common property institutions and sustainable governance of resources. World Development 29 (10):1649-1672.

Agrawal, A., and Yadama, G. (1997). How do local institutions mediate market and population pressures on resources? Forest Panchayats in Kumaon India. Development and Change 28 (3):435-465.

Anriquez, G., Stamoulis, K. (2007). Rural development and policy reduction: Is agriculture still the key? Rome: FAO. ESA Working Paper No. 07-02

Arato, A. (2000). Civil society, constitution, and legitimacy. New York: Columbia University Press.

Baland, J.M., Platteau, J.P. (1996). Halting degradation of natural resources: Is there a role for rural communities? Rome: Food \& Agriculture Organization.

Barham, J, Chitemi, C. (2008). Collective action initiatives to improve marketing performance lessons from farmer groups in Tanzania. Collective Action for property Rights (Capri). Working Paper, No.: 74. 
Berkes, F., (ed) (1989). Common property resources: Ecology and community-based sustainable development. London: Belhaven Press.

Bryman, A. (2008). Of methods and methodology. Qualitative Research in Organizations and Management International Journal, 3(2), 159168 https://doi.org/10.1108/17465640810900568.

CBS, (2011). National Population and Housing Census, Central Bureau of Statistics: Kathmandu, Nepal

Cheston, S. \& Kuhn, L. (2002). Empowering women through microfinance. http:// videos.opportunity.org/website/Empowering-Women-Paper.pdf (Retrieved March, 2017).

Clark, C.W. (1973). The economics of over exploitation. Science 181:630.

Clark, J. (1999). Democratizing development: The role of voluntary organizations. West Hartford: Kumarian Press.

Cohen, J. L., \&Arato, A. (1997). Civil society and political theory. Cambridge: MIT Press.

Curran-Everett D. (2017), Explorations in statistics: the assumption of normality. Adv Physiol. Educ. 41: 449-453, 2017; doi:10.1152/ advan.00064.2017

Davison, A. C. \& Hinkley, D. V. (1997). Bootstrap methods and their application. Cambridge University Press.

Day, G. (1994). Working with the grain? Toward sustainable rural and community development. Journal of Rural Studies 14: 89-105.

Edwards, M. \& Hulme, D.(1994). NGOs and development: Performance and accountability in the new World Order. Paper presented in International Workshop on NGOs and Development, University of Manchester.

Efron, B. \& Tibshirani, R. J. (1993). An Introduction to the bootstrap. New York: Chapman and Hall

Fowler, A. (1993). Non-governmental organizations as agents of democratization: An African Perspective. Journal of International Development, 5: 325339.

Frankish, J.(2003). Conceptualization and measurement of community capacity. Applied Research and Analysis Directorate (ARAD).

Friedmann, J. (1992). Empowerment: The politics of alternative development. Blackwell: Cambridge press. 
Foley, M. W. \& Edwards, B. (1996).The Paradox of civil society. Journal of Democracy 7(3), 38-52. Johns Hopkins University Press. Retrieved January 30, 2019, from Project MUSE database

Gittleson, J. (1996). Qualitative research in field trails. In: P.G. Smith and R.H. Morrow (eds), Field Trails in Health Interventions in Developing Countries: A Text Book. London: Macmillan.

Gittleson, J. and Mookherji, S. (1997). The application of anthropological methods to study the intra household resource allocation. In: L. Haddad, J. Hoddinott and H. Alderman (eds), Intra household Resource Allocation in Development Countries: Models, Methods, and Policy. Baltimore and London: The John Hopkins University press

Greene, J. C. (2007). Mixed methods in social inquiry. Journal of Mixed Methods Research, 2 (2), 190-192https://doi.org/10.1177\%2F1558689807314013

Hesterberg, T. C. (1999). Bootstrap tilting confidence intervals and hypothesis tests in computer science and statistics: Proc. 31st Symposium on the Interface 389-393. Interface Foundation of North America, Inc., Fairfax Station, VA.

Hibbard, M. Tang, C. C.( 2004). Sustainable Community Development: A Social Approach from Vietnam. Community Development Society, 35(2): 87105.

Johnson, R. B., Onwuegbuzie, A. \& Turner, L. (2007). Toward a definition of mixed methods research. Journal of Mixed Methods Research, pp 112.

Kellert, S.R., Mehta, J. N., Ebbin, S.A. Lichtenfeld, L.L. (2000). Community natural resource management: Promise, rhetoric, and reality. Society \& Natural Resources, 13:705-715.

Kelly, L. (1992). Community development: from technology to transformation. Unpublished Ph.D. Thesis. Melbourne: University of Melbourne.

Korten, D.C. (1990). Getting to the 21 st century: voluntary action and the global agenda. West Hartford, Conn: Kumarian Press.

Lancaster, G. (2005). Research methods in management: A concise introduction to research in management and business consultancy. Oxford: ButterworthHeinemann.

Langran, L.V. (2002). Empowerment and the limits of change: NGOs and health decentralization in the Philippine. Ph. D. Thesis, Toronto: University of Toronto. 
Larson, B.A., and Bromley, D.W. (1990). Property rights, externalities, and resource degradation: Locating the tragedy. Journal of Development Economics: 235-262.

Magingxa, L.L., Kamara, A.B. (2003). Institutional perspectives of enhancing smallholder market access in South Africa. A paper Presented at the Annual Conference of Agricultural Economic Association of South Africa.

Morgan, D. (2007). Paradigms lost and pragmatism regained: Methodological implications of combining qualitative and quantitative methods. Journal of Mixed Methods Research.1 48-76. https://doi. org/10.1177/2345678906292462.

Ostrom, E. (2005). Understanding institutional diversity. Public Choice 132: 509511.

Ostrom, E. (1992). Crafting institutions for self-governing irrigation systems. San Francisco: Institute for Contemporary Studies.

Ostrom, E. (1990). Governing the commons. New York: Cambridge.

Pretty, J. \& Ward, H. (2001).Social capital and the environment. World Development 29: 209-227.

Resnick, D. (2004). Smallholder African agriculture: progress and problems in confronting hunger and poverty. DSGD Discussion Paper No: 9, Washington D.C.: International Food Policy Research Institute.

Salami A, Kamara A.B, Brixiova, Z. (2010). Smallholder agriculture in East Africa: Trends, constraints and opportunities. Working Paper, No: 105.

Salamon, L. (1994). The rise of the non-profit sector. Foreign Affairs, 73: 109122.

Sick, D. (2008). Social contexts and consequences of institutional change in common pool resource management. Society and Natural Resources 21 (2): 94-105.

Uphoff, N., Buck, L. and Sjorslev, J. (2006). Strengthening rural local institutional capacities for sustainable livelihoods and equitable development. Social Development Department. Washington DC: The World Bank.

World Bank (2006). Uganda poverty and vulnerability assessment report, Report Number 36996-UG Poertu Reduction and Economic Management of Africa Regions. Washington DC 